\section{石炭灰スラリーを外割大量混合 したコンクリートの構造体強度 特性}

\title{
PROPERTY OF STRENGTH IN STRUCTURE OF THE CONCRETE USING HIGH VOLUME FLY ASH SLURRY AS A PART OF THE FINE AGGREGATE
}

高単幸二—— $* 1$

キーワード :

石炭灰スラリー，外割調合，模擬柱試験体，構造体強度，実機実験

Keywords :

Fly ash slurry, Mix proportion using fly ash as a part of the fine aggregate, Simulated column specimen, Strength in structure, Experiment by mixer of ready-mixed concrete plant

\section{Koji TAKASU—— $* 1$}

In the ready mixed concrete producer in Okinawa Prefecture, fly ash exhausted from the thermal power plant in Okinawa Prefecture was slurried. Simulated column specimens were made by concrete using high volume fly ash slurry. And property of strength in structure was clarified. The conclusions are as follows. It was able to be confirmed the concrete using high volume fly ash slurried by $60 \mathrm{wt} \%$ in the concentration was able to mix by an actual size mixer at ready-mixed concrete plant, and was able to make simulated column specimens by using it. Compressive strength of core concrete cylinder using fly ash content $50 \mathrm{~kg} / \mathrm{m}^{3}$ or more per unit volume of concrete after the 28th age was higher than standard curing cylinder on the 28th age.

\section{1.はじめに}

火力発電所などから発生する石炭灰発生量は，2005年に我が国で 1115 万t $\mathrm{t} ， 世$ 界全体では約 5 億 $\mathrm{t}$ 亿達している ${ }^{1)}$ 。近年，有効利用の促 進がめざましくその $90 \%$ 以上が有効利用されている。発生した石炭 灰の有効利用分野を見ると, 大半がセメント原料として利用されて いるが，今後，セメント原料以外の分野においても更なる有効利用 が望まれる。石炭灰をセメント代替ではなく，砂代替として調合す る外割調合則を確立させ，石炭灰外割混合コンクリートが無混合の コンクリートより高い強度発現性能及び高耐久性状を示すことを明 らかにしている2。また，石炭灰中の未燃カーボン除去を行うスラリ 一安定化処理技術を開発しており，同処理技術には，石炭灰をスラ リー化する工程が含まれ, 既往の研究3)によりスラリー化した方が乾 粉で使用するよりフレッシュコンクリートの流動性が向上すること を示している。今後，石炭灰外割混合コンクリートを実用化するに は，生コン工場における実機実験により構造体コンクリート強度の 性状を確認する必要がある。

本研究は, 沖縄県の生コン工場において沖縄県で発生した石炭灰 をスラリー化して，それを外割大量混合したコンクリートから模擬 柱試験体を作成し, その構造体コンクリートの強度性状を確認した。

\section{2. 実験概要}

\section{1 使用材料及び調合}

表1に使用材料を示す。沖縄県の火力発電所から発生した石炭灰を スラリー濃度 $60 \mathrm{wt} \%$ でスラリー化したものを使用した。スラリー濃 度 $60 \mathrm{wt} \%$ 程度なら液体として扱うことができ，水中ポンプで計量バ ッチャー内へ投入可能と考えた。なお，今回使用した石炭灰の強熱

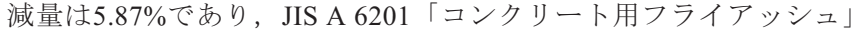

III種に適合する。また，骨材は沖縄県で産出されるものを使用した。 表2 に調合を示す。調合は単位水量, 単位セメント量をそれぞれ

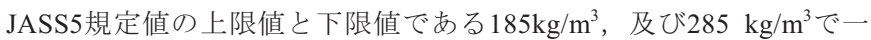
定とした。石炭灰無混合を基準調合，石炭灰を砂代替による外割混 合で $50 \mathrm{~kg} / \mathrm{m}^{3}, 100 \mathrm{~kg} / \mathrm{m}^{3}, 200 \mathrm{~kg} / \mathrm{m}^{3}$ の計4調合とした。フレッシュコ ンクリートの流動性は中流動タイプとし, 練り上がり時のスランプ フロー $45 \mathrm{~cm} \pm 5 \mathrm{~cm}$ ，空気量は $4.5 \% \pm 1.5 \%$ とした。

\begin{tabular}{|c|c|c|c|}
\hline 項目 & 種類 & 物性 & 記号 \\
\hline セメント & 普通ポルトランドセメント & 密度 $3.16 \mathrm{~g} / \mathrm{cm}^{3}$ & $\mathrm{C}$ \\
\hline 水 & 地下水 $\cdot$ 上澄水 & JIS A 5308附属書 3 に適合 & $\mathrm{W}$ \\
\hline \multirow{2}{*}{ 細骨材 } & \begin{tabular}{|l} 
海砂 \\
沖縄県東村新川沖産
\end{tabular} & $\begin{array}{l}\text { 密度 } 2.60 \mathrm{~g} / \mathrm{cm}^{3} \\
\text { 吸水率 } \quad 0.73 \% \\
\text { 粗粒率 } 2.45\end{array}$ & $\mathrm{~S}_{1}$ \\
\hline & $\begin{array}{l}\text { 砕砂 } \\
\text { 沖縄県本部半島産 }\end{array}$ & $\begin{array}{ll}\text { 密度 } \quad 2.66 \mathrm{~g} / \mathrm{cm}^{3} \\
\text { 吸水率 } \quad 2.10 \% \\
\text { 粗粒率 } 3.00\end{array}$ & $\mathrm{~S}_{2}$ \\
\hline 粗骨材 & $\begin{array}{l}\text { 砕石 } \\
\text { 沖縄県本部半島産 }\end{array}$ & $\begin{array}{l}\text { 密度 } \quad 2.70 \mathrm{~g} / \mathrm{cm}^{3} \\
\text { 実積率 } \quad 59.3 \%\end{array}$ & G \\
\hline 混和材 & 石炭灰 & 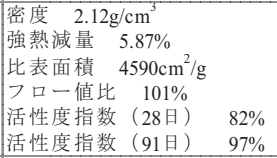 & FA \\
\hline \multirow{2}{*}{ 混和剤 } & 高性能AE減水郕 標準形 & $\begin{array}{l}\text { ポリカルボン酸エーテル系 } \\
\text { 密度 } 1.06 \mathrm{~g} / \mathrm{cm}^{3}\end{array}$ & AD1 \\
\hline & AE剂 & $\begin{array}{l}\text { アルキルエーテル系 } \\
\text { 密度 } 1.03 \mathrm{~g} / \mathrm{cm}^{3}\end{array}$ & $\mathrm{AD} 2$ \\
\hline
\end{tabular}

表 2 調合

\begin{tabular}{|c|c|c|c|c|c|c|c|c|c|}
\hline \multirow[t]{2}{*}{ 表合記号 } & \multirow{2}{*}{$\begin{array}{l}\mathrm{W} / \mathrm{C} \\
(\%)\end{array}$} & \multicolumn{6}{|c|}{ 単位質量 $\left(\mathrm{kg} / \mathrm{m}^{3}\right)$} & \multicolumn{2}{|c|}{$\begin{array}{c}\text { 混和剤 } \\
\times(\mathrm{C}+\mathrm{F})(\%) \\
\end{array}$} \\
\hline & & $\mathrm{W}$ & $\mathrm{C}$ & FA & $\mathrm{S}_{1}$ & $\mathrm{~S}_{2}$ & $\mathrm{G}$ & AD1 & $\mathrm{AD} 2$ \\
\hline FA-0 & \multirow{4}{*}{65} & \multirow{4}{*}{185} & \multirow{4}{*}{285} & 0 & 539 & 359 & \multirow{4}{*}{910} & 0.5 & 0.015 \\
\hline FA-50 & & & & 50 & 502 & 274 & & 0.5 & 0.06 \\
\hline FA- 100 & & & & 100 & 465 & 311 & & 0.6 & 0.12 \\
\hline FA-200 & & & & 200 & 392 & 262 & & 0.7 & 0.12 \\
\hline
\end{tabular}

*1 Assoc. Prof., Dept. of Architecture, Faculty of Environmental Eng., The Univ. of

Kitakyushu, Dr. Eng.
*1 北九州市立大学国際環境工学部建築デザイン学科 准教授・工博 （†808-0135＼cjkstart北九州市若松区ひびきの1-1） 
表 3 測定項目

\begin{tabular}{|c|c|c|c|}
\hline & 測定項目 & 試験方法 & 備考 \\
\hline \multirow{2}{*}{ フレッシュコンクリート } & スランプフロー & JIS A 1150 & \multirow{2}{*}{ 練り上がり, 30 分, 60 分, 90 分後に測定 } \\
\hline & 空気量 & JIS A 1128 & \\
\hline \multirow{2}{*}{ 硬化コンクリート } & 圧縮強度 & JIS A 1108 & 模擬柱試験体コア中心, コア端部 \\
\hline & 静弾性係数 & JIS A 1149 & 標準養生, 簡易断熱養生, 現場封緘養生, 現場気中養生 \\
\hline その他 & 模擬柱試䮦体温度 & - & 中心部温度, 端部温度の経時変化測定 \\
\hline
\end{tabular}

\section{2 測定項目及び試験体の打設方法}

打設は2006年10月29日に沖縄県沖縄市の生コン工場で実施した。 沖縄県で実施したので若干暑い中間期に該当する。コンクリートの 練混ぜには, 生コン工場の容量 $3 \mathrm{~m}^{3}$ 強制二軸練りミキサーを使用し, セメント，細骨材，石炭灰スラリー，水，粗骨材の順に投入した。 練り上がり後30分間アジテータ車で覺拌した後, 所定の型枠に打設 した。模擬柱試験体の打設には棒状バイブレーターによる締固めを 行った。図1に模擬柱試験体形状及びコア採取位置を示す4)。模擬柱 試験体は $1000 \mathrm{~mm}$ の立方柱で上下面を $200 \mathrm{~mm}$ の発砲ポリスチレン板 で7日間断熱した。模擬柱試験体は各調合に対してそれぞれ作成し計 4体作成した。写真 1 に模擬柱試験体の打設状況及び脱型後の様子を 示す。表 3,4 に測定項目及び圧縮試験概要を示す。模擬柱試験体の 中心部と端部に熱電対を取り付けて7日間温度履歴を計測した。圧縮

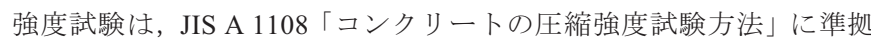

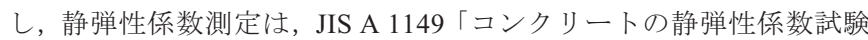
法」に準じた。養生の種類及び材齢は表4に示している。材齢28日， 56日，91日，365日のコア供試体の圧縮強度を測定するため，試験材 齢の 2 日前にコアボーリングにより $\phi 100 \times 1000$ のコアを採取し, 図 1 に示す場所でコアをカットし $\phi 100 \times 200$ の供試体を 3 本切り出した。 コア採取位置は各材齢につき中心部, 及び端部の2力所である。写真 2にコアボーリングの様子及びコア供試体を示す。

\section{3. 実験結果及び考察}

\section{1 コンクリートの練混ぜ}

今回の練混ぜでは，スラリー効果を得るため，石炭灰をスラリー 濃度 $60 \mathrm{wt} \%$ でスラリー化したものを水中ポンプにより計量バッチャ 一の中に投入した。スラリー濃度 $60 \mathrm{wt} \%$ 程度ならば液体として扱う ことが可能であり，水の計量と同様にしてコンクリートミキサーの 中に投入することができた。練混ぜ中の様子も石炭灰無混合の基準 調合と同様であることが確認できた。

\section{2 フレッシュコンクリートの性状}

図2にスランプフローの経時変化を示 す。FA-50及びFA-100のスランプフローは， 基準調合であるFA-0 と同様な経時変化を 示した。FA-200は練り上がり後30分以降, スランプフローロスが顕著に確認された。 既往の文献5)では，JIS II 種に適合する石 炭灰を大量混合しても顕著なスランプフ ローロス，空気量ロスが確認されていな いので, 石炭灰の強熱減量が5.87\% と大き かったことが原因であると考えられる。 図3に空気量の経時変化を示す。FA-0, FA-50, FA-100の空気量の経時変化はほぼ 一定であった。FA-200は練り上がり初期

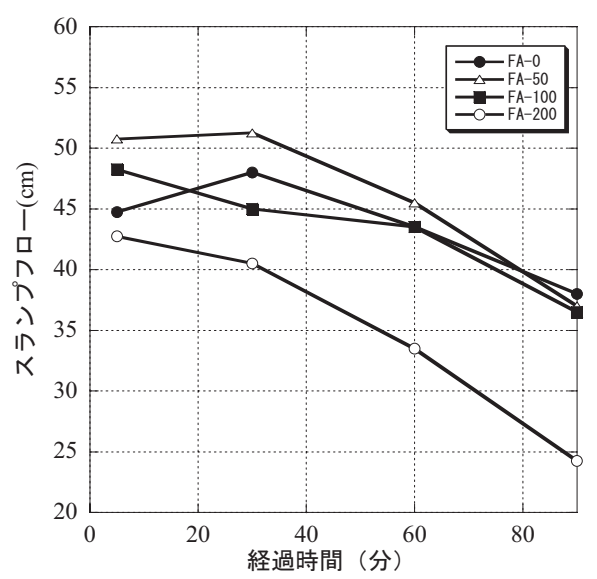

図 2 スランプフローの経時変化
表 4 圧縮試験概要

\begin{tabular}{|c|c|c|c|c|c|c|c|c|}
\hline \multirow{2}{*}{ 試験体の種類 } & \multirow{2}{*}{ 試験体の形状 } & \multicolumn{7}{|c|}{$\begin{array}{l}\text { 試験材齢 (日) } \\
\end{array}$} \\
\hline & & 1 & 3 & 7 & 28 & 56 & 91 & 365 \\
\hline 模擬柱試験体コア中心 & \multirow{2}{*}{ コア $100 \phi \times 200 \mathrm{~mm}$} & 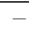 & - & - & 0 & 0 & 0 & 0 \\
\hline 模擬柱試験体コア端部 & & - & - & - & 0 & 0 & 0 & 0 \\
\hline 標準養生 & \multirow{4}{*}{$100 \phi \times 200 \mathrm{~mm}$} & - & 0 & 0 & 0 & 0 & 0 & 0 \\
\hline 簡易断熱養生 & & - & - & - & 0 & 0 & $\mathrm{O}$ & - \\
\hline 現場封緘養生 & & $\mathrm{O}$ & 0 & 0 & 0 & - & 0 & - \\
\hline 現場気中養生 & & - & 0 & 0 & 0 & - & 0 & - \\
\hline
\end{tabular}

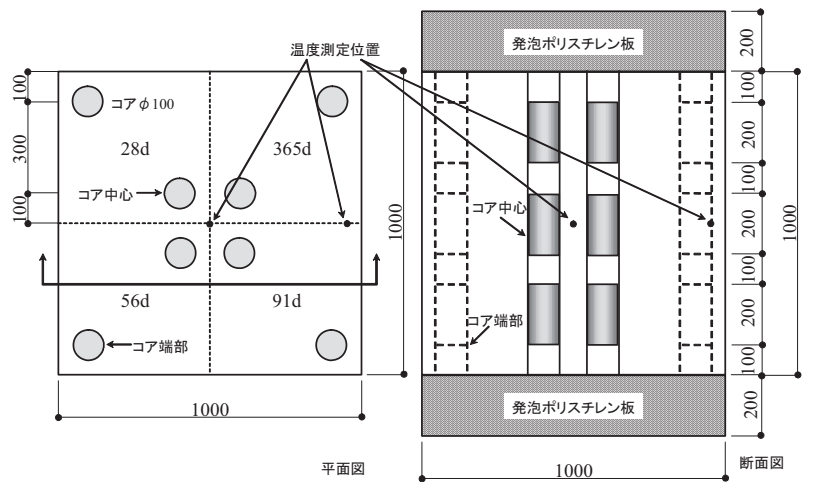

図 1 模擬柱試験体形状及びコア採取位置
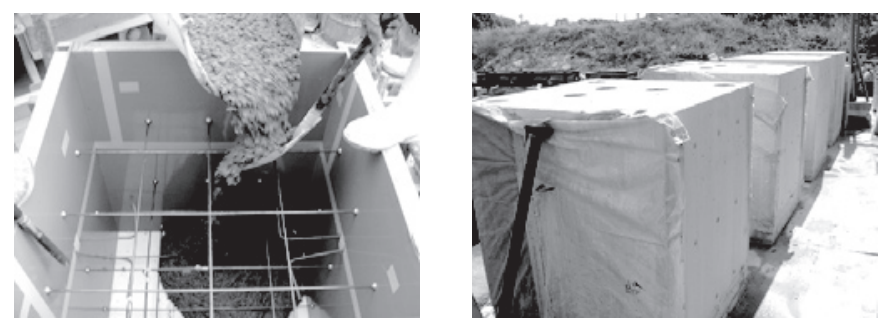

写真 1 模擬柱試験体の打設状況及び脱型後の様子
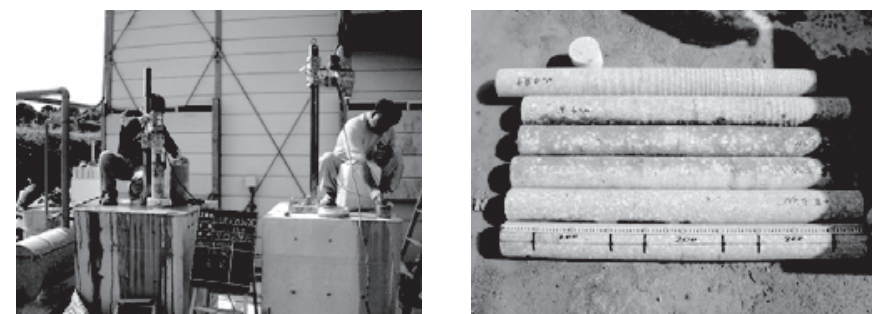

写真 2 コアボーリングの様子及びコア供試体 . 


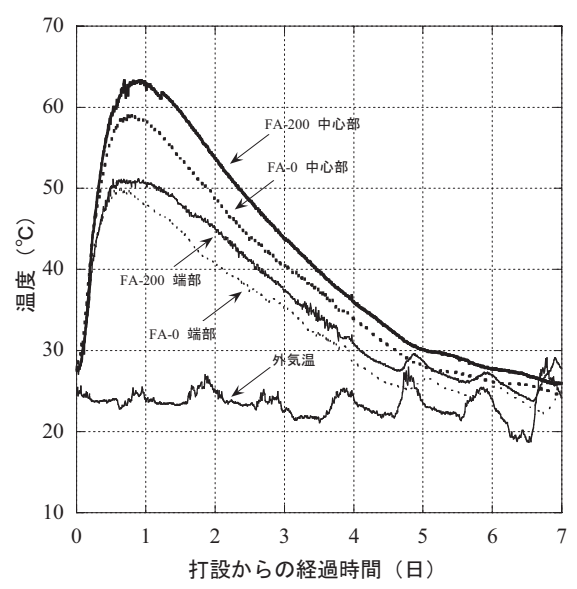

図 4 模擬柱試験体の温度履歴

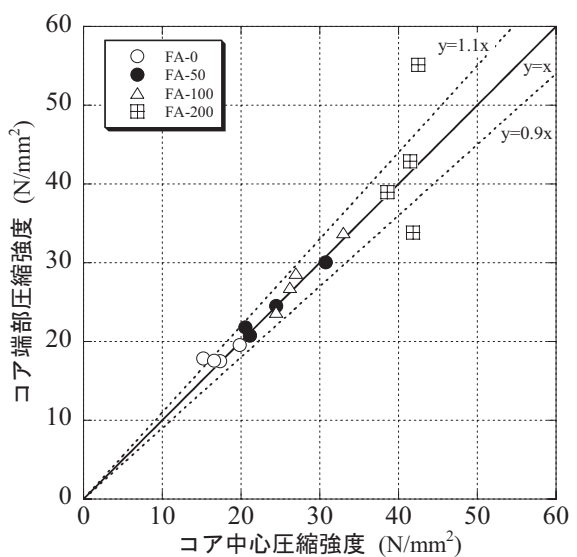

図 7 コア中心と端部の圧縮強度の関係

から顕著な空気量ロスを生じた。石炭灰を 外割で $100 \mathrm{~kg} / \mathrm{m}^{3}$ 程度混入する場合, 強熱減 量値がJIS III 種に適合する石炭灰を使用し てもフレッシュコンクリートに与える影 響は少ないが， $200 \mathrm{~kg} / \mathrm{m}^{3}$ 以上と大量に外割 混合する場合は強熱減量の管理が重要で ある。このような石炭灰をコンクリート中 に大量に使用するには浮遊選鉱法により 未燃カーボンを除去して安定化したもの を使用する必要がある。

\section{3 コンクリートの温度履歴}

図4に模擬柱試験体の中心部及び端部の打設後 7 日までの温度履歴 を示す。打設から最高温度に達するまでの中心部の温度上昇量は $\mathrm{FA}-0$ で $31.4^{\circ} \mathrm{C} ， \mathrm{FA}-200$ で $35.8^{\circ} \mathrm{C}$ となり，端部の温度上昇量は中心部 より FA-0 で $9.3^{\circ} \mathrm{C}$, FA-200で $12.2^{\circ} \mathrm{C}$ 低くなっていた。石炭灰無混合の ものと $200 \mathrm{~kg} / \mathrm{m}^{3}$ 混合したものの温度履歴は若干最高温度に差がある が概ね同様な傾向を示した。なお, 強度特性に関して次項で記すが, 石炭灰無混合コンクリートより少ないセメント量で同等の強度が確 保できるので，石炭灰を外割大量混合すると同等の強度の石炭灰無 混合コンクリートより内部温度上昇の抑制に大きな効果を発揮する ことができる。

\section{4 圧縮強度}

図5に材齢365日までの圧縮強度の経時変化, 図6に圧縮強度と単位

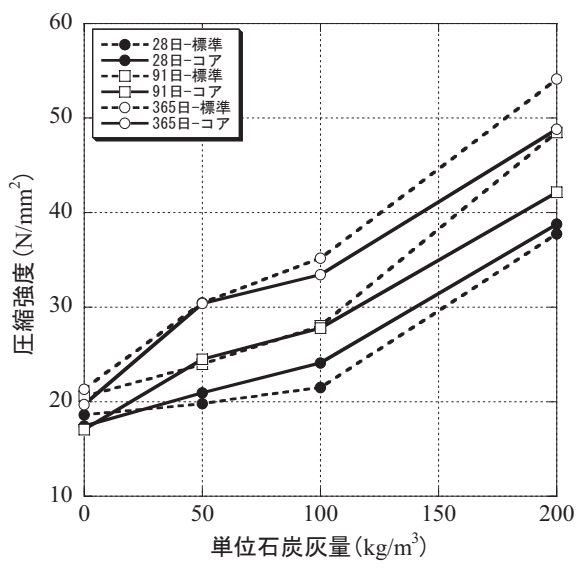

図 6 圧縮強度と単位石炭灰量の関係
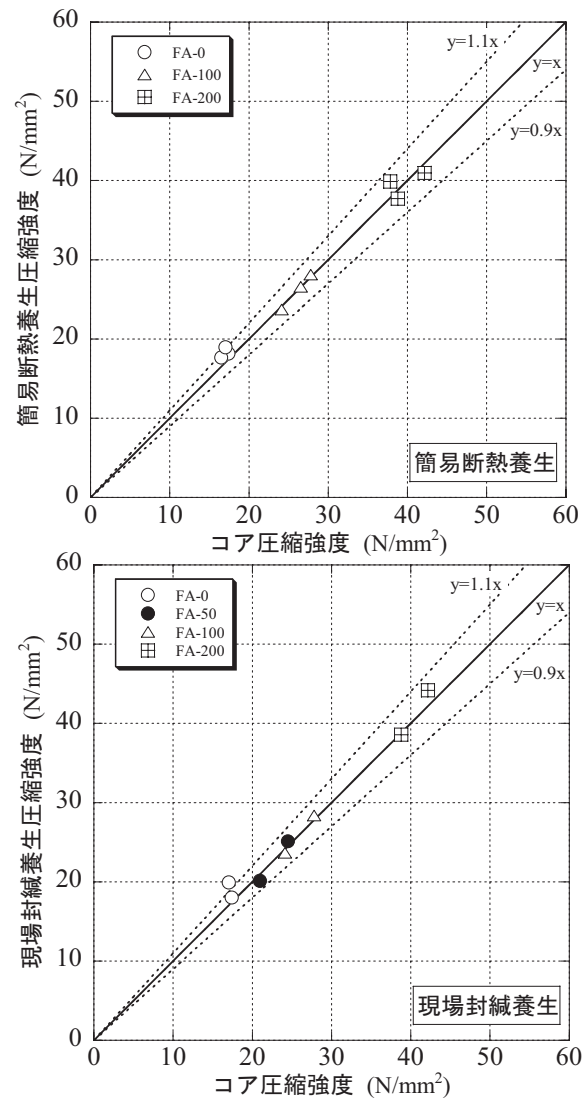

現場気中養生

コア圧縮強度 $\left(\mathrm{N} / \mathrm{mm}^{2}\right)$
石炭灰量の関係を示す。ここでコア強度とはコア中心部と端部の平 均值である。FA-200は，材齢初期からFA-0の2倍程度の圧縮強度を 示している。圧縮強度は全ての調合において材齢365日まで増加傾向 を示すが, 石炭灰の混合量が増加するほど強度増進も大きくなった。 生コン工場の実機においても石炭灰を外割混合すると無混合よりは 圧縮強度増進に効果を発揮することが明らかになった。FA-0のコ ア端部の強度に対してFA-100, FA-200のコア端部の強度は材齢とと もに強度が増進した。FA-200のコア中心部強度は材齢91日以後増進 が認められなかった。標準養生供試体は石炭灰を $100 \mathrm{~kg} / \mathrm{m}^{3}$ まで混合 したときの無混合に対する強度増進量より $200 \mathrm{~kg} / \mathrm{m}^{3}$ まで混合したと きの増進量の方が大きく, 石炭灰大量混合の効果が窥えた。またコ ア供試体はほぼ直線的に強度が増加した。 

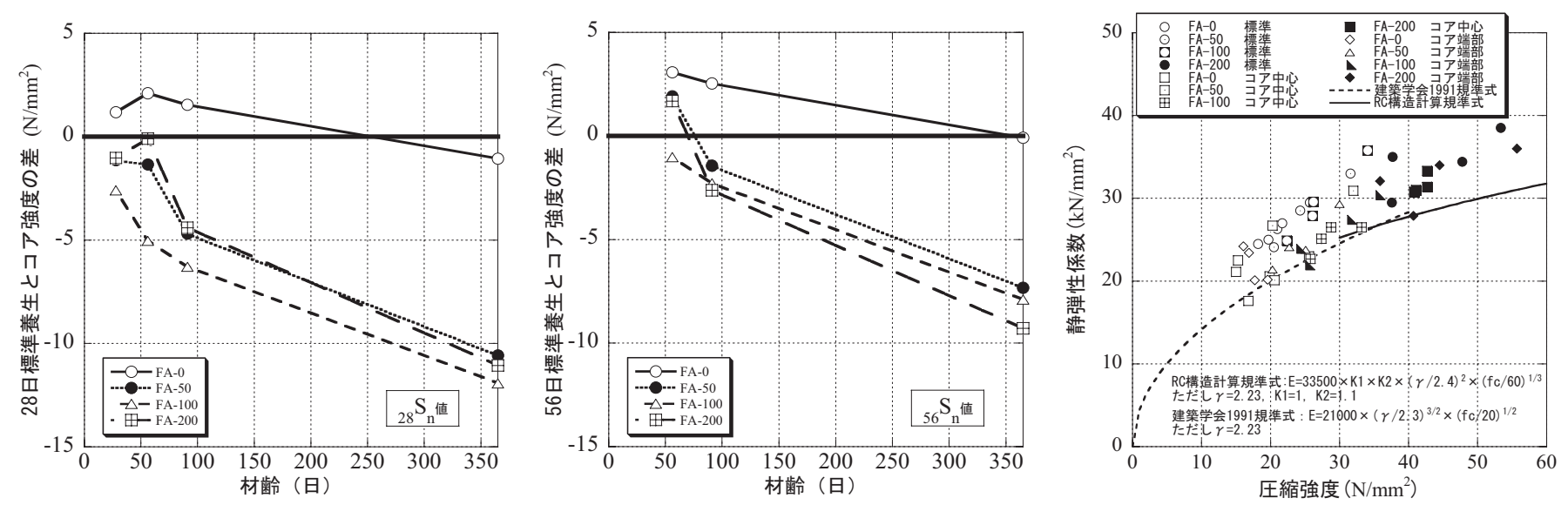

図 9 標準養生強度と各材齢コア強度の差

図 10 圧縮強度と静弾性係数の関係

図7にコア中心部と端部における圧縮強度の関係を示す。FA-0か らFA-100まではコア中心と端部に圧縮強度の違いは見られなかっ たが，FA-200には両者の間にばらつきを生じた。コア中心部と端部 では最大 $12.2^{\circ} \mathrm{C}$ の温度差が生じていたが，石炭灰無混合の温度履歴 と概衫同様な傾向を示しており，打設状沉にも問題はなかった。単 位石炭灰量の増加, 若しくはそれによる圧縮強度の増加がコア中心 と端部にばらつきを生じた可能性はあるが，本実験でそれを断定す ることは難しく, 今後多くの実験検証が必要である。

図8にコア強度と各種養生条件における強度の関係を示す。FA-0 とFA-200ではコア強度より標準養生供試体の方が高くなる場合が 多く,FA-200には両者の強度の間にばらつきも認められた。石炭灰 を混合した調合の現場気中養生供試体とコア強度の関係は全体的に コア強度の方が大きな值を示した。石炭灰を混合した調合の簡易断 熱養生供試体とコア強度, 及び現場封縅養生供試体とコア強度はか なり近い值を示した。従って本実験の範囲内において簡易断熱養生 と現場封縅養生供試体から, 構造体コンクリート強度をある程度推 定することができる。

図9に28日標準養生強度及び56日標準養生強度と材齢n日コア強度 との差 $\left({ }_{28} \mathrm{~S}_{\mathrm{n}},{ }_{56} \mathrm{~S}_{\mathrm{n}}\right)$ を示す。石炭灰無混合のFA-0は 28 日標準養生強 度とコア強度との差は材齢91日までは正の值を示し, 365 日コア強度 との差になると負の值になった。石炭灰を $50 \mathrm{~kg} / \mathrm{m}^{3}$ 以上外割混合する と28日以後の 28 日標準養生強度とコア強度の差は常に負の值を示し た。特に材齢が経過するほど差が小さくなった。56日標準養生強度 と56日コア強度との差はFA-100以外正の值になったが, それ以降の 材齢では石炭灰を外割混合すると負の值を示し，28日標準養生強度 とコア強度の差と同様な傾向を示した。従って, 本実験の範囲内に おいて石炭灰を $50 \mathrm{~kg} / \mathrm{m}^{3}$ 以上外割混合した構造体コンクリート強度 は，S值を 0 とすることで材齢28日の標準養生供試体の圧縮強度によ り常に安全側に管理することが可能である。

\section{5 静弾性係数}

図10に圧縮強度と静弾性係数の関係を示す。FA-200は標準養生, コア中心，コア端部において概ねRC構造計算規準式より上側に分布 した。FA-200の圧縮強度と静弾性係数の関係に標準養生とコアの違 いは認められなかった。FA-50, FA-100の標準養生は概ね建築学会 1991規準式の上側に分布し, コアは概ね規準式上に分布した。本実 験の範囲内において実機による石炭灰外割混合コンクリートの圧縮 強度と静弾性係数の関係は概称建築学会1991規準式及びRC構造計
算規準式のに対して $37.0 〜-4.2 \%$ の範囲に入っており規準式より若干 大きな值を示したが，概ね既往の規準式で評価できる。

\section{4.まとめ}

以下に得られた知見を要約して示す。

(1) スラリー濃度 $60 \mathrm{wt} \%$ でスラリー化した石炭灰を外割混合したコ ンクリートは生コン工場の実機プラントで練混ぜ可能であり，実大 試験体も作成可能であることが確認できた。

(2) 石炭灰無混合のものと $200 \mathrm{~kg} / \mathrm{m}^{3}$ 混合したものの温度履歴に大き な変化は生じず同様な傾向を示した。

（3）石炭灰を外割混合した場合, 簡易断熱養生と現場封縅養生の供 試体から，構造体コンクリート強度をある程度推定することができ る。

(4) 石炭灰を $50 \mathrm{~kg} / \mathrm{m}^{3}$ 以上外割混合した構造体コンクリート強度は, 28 日以後の 28 日標準養生強度とコア強度の差は常に負の值を示し, $\mathrm{S}$ 值を 0 とすることで材齢28日の標準養生供試体の圧縮強度により常 に安全側に管理することが可能である。

(5) 実機による石炭灰外割混合コンクリートの圧縮強度と静弾性係 数の関係は概放建築学会1991規準式及びRC式構造計算規準式で評 価できる。

\section{《謝辞》}

本研究は, 平成18～19年度, 文部科学省研究費補助金基盤研究(C)「フライ アッシュをセメント外割混合するコンクリートの養生則」課題番号 18560558(研究代表者 松藤泰典)の支援を受けて行った。実験に際して, 本学 $\mathrm{EA} \cdot$ 三島剛氏, 及び三倉英史氏, 並びに本学修論生・北村利英君（現：清水 建設㑣），林田拓也君（現：(怢大林組）, 卒論生・嵩原克佳君（現：(怢才リ バー）に協力して頂いた。株式会社E-CONから実機プラントを使用させて頂 いた。末尾に記して謝意を表す。

\section{《参考文献》}

1) “石炭灰実態調査”, JCOAL（財）石炭エネルギーセンター, 2008-6-11, http://www.jcoal.or.jp/coalash/coalash.html，（参照2008-6-15）

2) 松藤泰典他: 石炭灰を外割大量使用するコンクリートの調合に関する研究, コンクリート工学論文集, Vol.12, No.2, pp.51-60, 2001

3) 高巣幸二他: コンクリート用石炭灰安定化処理におけるスラリー過程に関 する電顕考察, 日本建築学会学術講演梗概集 (九州) , A-1,pp.407-408, 2007.9 4) 桝田佳寛他: 高強度コンクリートの施工技術の現状, 建築技術, p.109,2007.3

5) 松本尚樹他: フライアッシュを外割混合したコンクリートの実機生コンエ 場における製造実験, 日本建築学会研究報告九州支部, No.45・1, pp.33-36, 2006.3

6) 日本建築学会 : 鉄筋コンクリート構造計算規準・同解説 $1999,1999.11$ 